\title{
Subjetividade, Saúde e Trabalho
}

| Kenneth Rochel de Camargo Jr. |

As relações entre o mundo de trabalho e o processo saúde-doença têm uma longa tradição no campo da Saúde Coletiva, remontando aos primórdios da então chamada Medicina Social, com Virchow, e mesmo antes, como por exemplo, na monografia de Engels sobre as classes trabalhadoras na Inglaterra, que dedicava atenção especial à saúde dos operários. O tema deste número da Physis, encerrando o seu décimo nono volume, traz uma atualização a essa discussão, refletindo a partir da perspectiva da subjetividade. Abrindo o conjunto de artigos temáticos, Navarro e Cardoso discutem conceitos relativos à biossegurança a partir do referencial da subjetividade, como um dos elementos para a elaboração e superação dos contextos de risco. Costa e Tambellini analisam, a partir de pesquisas empíricas, as ameaças da precarização das relações de trabalho ao bem-estar dos trabalhadores em saúde. Bianchessi e Tittoni examinam o sofrimento de trabalhadores de saúde, com base nas experiências de pesquisa-intervenção em contexto hospitalar, destacando a percepção de desvalorização e invisibilidade do próprio trabalho como fator gerador de sofrimento. Finalmente, Moreira, Santos e Caetano encerram a seção com a experiência de uma intervenção de educação em saúde no tratamento de trabalhadores hipertensos, mostrando as potencialidades da estratégia descrita na adesão ao tratamento, questão estratégica no enfrentamento deste problema de saúde, com grande prevalência em nosso país.

Nos temas livres, Baptista, Fausto e Cunha apresentam uma análise da produção bibliográfica sobre atenção primária publicada em quatro revistas do campo, identificando a carência de maior abordagem teórica e conceitual do tema. Ianni lança um desafio ao campo, sobre a necessidade de repensar seu próprio referencial teórico-epistemológico face ao desenvolvimento e difusão cada vez maiores das práticas biotecnológicas. Fernandes apresenta estudo sobre a reificação operada no marco da ciência de concepções ideológicas sobre 
a pretensa inferioridade feminina. Souza e Brandão descrevem o descompasso entre as normas prescritas e a realidade do acesso (ou falta de) à contracepção de emergência na atenção pública à saúde. Guedes, Pitombo e Barros fazem o relato de uma experiência de treinamento de gestores e trabalhadores de saúde no marco da Política Nacional de Humanização. Paula, Alves, Vieira e Souza fazem uma análise histórica da política de medicamentos no Brasil, ressaltando sua importância estratégica para a política de saúde em geral. Anjos e Duarte analisam os currículos de faculdades de Educação Física, assinalando a incompatibilidade relativa destas com as novas demandas colocadas aos profissionais daquela área a partir das redefinições e expansão das açôes de saúde no marco da Estratégia de Saúde da Família. Canguçu-Campinho, Bastos e Lima trazem seu estudo da produção bibliográfica sobre intersexualidade em diversos campos científicos, apresentando interessante análise comparativa sobre as diferentes ênfases e abordagens na literatura. Brzozowski e Caponi descrevem as repercussões do diagnóstico de TDAH em pais, professores e crianças, como exemplo de articulação entre discursos de especialistas e as concepçôes daqueles afetados por elas. Silveira, Vianna e Mosegui encerram a seção com um estudo das normas brasileiras sobre os chamados alimentos funcionais, mostrando as incoerências destas com outras normatizações sobre produtos ligados ao mercado da saúde, em particular os medicamentos. Mantivemos este último texto em inglês, a pedido dos autores.

$\mathrm{Na}$ seção de resenhas, Hammerschmidt e Santos discutem Família: redes, laços e políticas públicas, de Ana Rojas Acosta e Maria Amália Faller Vitale.

O próximo número de Physis marcará seu vigésimo ano de existência. A partir deste ano, o gerenciamento da revista passa a ser totalmente eletrônico, pelo sistema SciELO. A submissão de artigos e o acompanhamento de sua avaliação serão feitos online, com maior transparência para todos os envolvidos. Pretendemos continuar o processo de aprimoramento de nossa revista, contando com a colaboração dos autores e em particular dos revisores, a quem dedicamos nosso agradecimento nominando-os ao final desta edição. Convidamos todos os leitores a participar de Physis, também por meio de cartas, às quais também pretendemos dedicar seção própria.

Feliz Ano Novo! 